Luther's era nor Luther's insistence that spiritual duties existed in both realms. Carty thus concludes: "Luther's influence on the development of the modern secular state $[\ldots]$ can perhaps be best argued as an indirect and unintentional consequence of this political thought" (175).

A few minor technical issues flaw an otherwise masterful tome. There is no index of Scripture citations, bizarre in light of chapter 3's focus on Luther's biblical interpretation. "Tyrannicide" and "holy orders," key concepts analyzed, are not in the index. More surprising, given allegations that Luther's theology was foundational to fascism, "National Socialist" is not indexed. This reviewer noted only three typos.

C. MARK STEINACHER

Tyndale Seminary

\title{
Castellion, Sébastien.
}

Conseil à la France désolée. Ed. Florence Alazard, Stéphan Geonget, Laurent Gerbier, Paul-Alexis Mellet, and Romain Menini.

Geneva: Droz, 2017. Pp. clxxxi, 110. ISBN 978-2-600-05835-3 (paperback) $19.80 \mathrm{CFH}$.

This book is a critical edition of Sébastien Castellion's Conseil à la France désolée. It seeks to give a detailed analysis of the text and its different contexts as well as to provide the edition that is now available in Gallica. The text itself is complemented by a thorough analysis, many footnotes, a chronology of notable events in Castellion's life, and a bibliography and index. The editors are four researchers from the University of Tours-Florence Alazard, Stéphan Geonget, Laurent Gerbier, and Paul-Alexis Mellet-and Romain Menini, a researcher at Université Paris-Est Marne-La Vallée.

Florence Alazard specializes in the cultural and political history of the Renaissance. Stéphan Geonget analyzes relationships between both literature and law and literature and fiction in the period. Laurent Gerbier researches the moral and political philosophy of the sixteenth century. Paul Alexis-Mellet studies the history of the state and the wars of religion in Europe, while Romain Menini focuses on Rabelais and how classical Antiquity was received in the Renaissance. This book is addressed to Renaissance specialists. 
The edition commences with an introduction divided into four parts: a general introduction, a study of the form and construction of the text, an examination of the moral, theological, and political aspects of the text, and an analysis of the destiny and uses of le Conseil. In the general introduction, the editors provide a short biography of Castellion's life. They also discuss the teachings of le Conseil and its historical context. In the part on form and construction, the editors examine genre, structure, and intended readers; they discuss legal and medical aspects; they analyze all the different structural elements of the text before developing a detailed plan of its entire structure. Furthermore, the editors analyze questions of authorship and the text's intended readers, while looking at language and diction. In their study of the moral, theological, and political aspects of the text, the editors analyze the moral of $l e$ Conseil, whether it is a theological treatise, its place in the theological polemics of the time, Castellion's view of Catholics in the early 1560s in France, the political stakes of le Conseil, and if it is a political text. The introduction finishes with a focus on the destiny and uses of the text, and discusses why le Conseil is the work of both a thinker and a poet.

The text itself contains many footnotes. These shed light on crossreferences to biblical texts and other texts of the Renaissance; they look at historical and linguistic explanations; they detail references to the same text so as to contextualize Castellion's words; they provide explanations of Castellion's historical references; they put forward references to texts that explain le Conseil and shed light on other publications to which the text refers; finally, they elucidate textual allusions and provide conjectures as to the meaning of certain passages.

The introduction to this text is thorough and well worth the read. It is remarkable in the way it sets the stage for the reading of the edition and in how many aspects or considerations are discussed. It is certainly important to note the effort and detail that must have gone into its development.

The footnotes are very helpful for the reader who wishes to understand this text in detail. Their number shows what pains were taken to ensure that the edition would be understood by any Renaissance specialist. The bibliography, too, is an indispensable source of references to editions from the Renaissance, modern editions, critical editions, translations, and critical studies.

This critical edition deserves to be read by all who are interested in the life and work of Sebastien Castellion. Not only does it come with an excellent 
explanatory introduction, but it also illuminates the meaning of the text in great detail and points the way to future studies. It is certainly wished that other critical editions of Renaissance texts would follow the model provided by this example. Although this preliminary text is lengthy, it is a useful resource for the scholar studying le Conseil because it makes the text more accessible. It is also therefore helpful to the reader who is studying le Conseil for the first time. While the text itself is very interesting and, as noted, available on Gallica, the strength of this edition is in its critical apparatus. This edition will be useful to all Renaissance specialists.

VIVEK RAMAKRISHNAN

Burlington, ON

\section{Cazals, Géraldine et Stéphan Geonget, éds.}

Les recueils de Plaidoyez à la Renaissance entre droit et littérature.

Genève : Droz, 2018. 332 p. ISBN 978-2-600-05814-8 (broché) 53 CFH.

On ne peut que saluer la parution d'une étude consacrée à la vogue des plaidoyers publiés à la Renaissance. Dans le sillage des recherches récentes qui ont mis au goût du jour les liens entre droit et littérature à l'époque prémoderne (voir en particulier Écrivains juristes et juristes écrivains du Moyen Âge au siècle des Lumières, édité par Bruno Méniel), ce nouvel opus vient combler une lacune en s'intéressant à un genre qui fut central en son temps (au moins une quarantaine de recueils de plaidoyers furent imprimés aux $\mathrm{XVI}^{\mathrm{e}}$ et $\mathrm{XVII}^{\mathrm{e}}$ siècles). Les éditeurs, Géraldine Cazals et Stéphan Geonget, qui avaient déjà édité en 2014 un collectif sur les « arrêts notables », rappellent à juste titre dans leur introduction que si la plaidoirie connaît actuellement une crise évidente dans les pratiques judiciaires françaises, l'époque prémoderne se caractérisait au contraire par «l'âge d'or des plaidoyers " (9). Cet essor n'empêchait pas certains des parlementaires les plus éminents (comme Du Vair, Pasquier ou Louis Caron, étudié ici par Stephan Geonget) d'entretenir un rapport très ambivalent avec l'art du plaidoyer et de critiquer notamment l'excès de la "rhétorique des citations» qui nuisait à l'argument. Les quatorze chapitres édités ici donnent une image synthétique de ce que fut cet âge d'or, marqué par la « plasticité » et par « des styles pour le moins diversifiés » (13). 